\title{
ESTABLISHMENT AND MANAGEMENT OF TAGASASTE
}

R.J. TOWNSEND and J.E. RADCLIFFE

Canterbury Agricultural Science Centre, MAF, Lincoln

\begin{abstract}
Tagasaste was successfully established from spring sown seed, drilled into cultivated ground and into herbicide.treated pasture $(55 \%$ and $40 \%$ of viable seed established respectively after 12 weeks) when spring soil temperatures reached about $13^{\circ} \mathrm{C}($ at $10 \mathrm{~cm})$. Seed drilled into short pasture suffered from plant competition and seed broadcast onto herbicide-treated and short pastures failed to establish (each $<7 \%$ establishment after 12 weeks). Mid September short pastures failed to establish (each $<7 \%$ establishment after 12 weeks). Mid September
sowings were slower to establish than October or November sowings because of cooler soils.

Established plants, in rows (equivalent to 10,000 plants/ha) on two hill sites and cut either once or twice per year to $30 \mathrm{~cm}$, gave a mean annual production of $1.6 \mathrm{~kg} \mathrm{DM} / \mathrm{plant}$. In another trial established plants cut to $50 \mathrm{~cm}$ in August, or December, or both these times, subsequently produced more dry matter than plants grazed by sheep at these times. Guidelines for establishing and managing tagasaste are given.
\end{abstract}

Keywords: tree lucerne, Chamaecytisos palmensis, sowing time, drilling, broadcasting, defoliation, cutting, grazing, production.

\section{INTRODUCTION}

Tagasaste (Chamaecytisus palmensis) formerly known as tree lucerne, is a drought tolerant, perennial, leguminous small tree presently being researched for its fodder potential. Rooted seedlings, sold commercially, give effective but costly establishment, and in Canterbury, seedlings planted in spring grow better than those planted in autumn (D.J.G. Davies, pers. comm). Seed sowing methods have received little attention. This paper reports establishment of tagasaste from seed, using drilling methods applicable to easy country and oversowing methods applicable to steeplands. Sowing methods were studied at three spring sowing dates at two sites.

Tagasaste grows into a small branched tree about $5 \mathrm{~m}$ high but young trees coppice when cut. Leafy stems may be cut for stock, or grazed in situ. This paper also reports on the production of established stands at two sites, when cut for six years, together with results from a preliminary trial where established plants were either cut or grazed or both cut and grazed.

\section{EXPERIMENTAL}

\section{Establishment Trials}

Methods. Two rabbit-proofed sites in Canterbury, one near Burnham on a Lismore stony silt loam soil of $\mathrm{pH} 6.2$ (light soil) and the other at Springston on a Templeton deep silt loam soil of $\mathrm{pH} 6.4$ (deep soil) were sown in mid September, October or November 1985. Seed was drilled into cultivated ground and either drilled into, or broadcast on, herbicide-treated or short pastures.

A "Duncan Multi-Seeder 734" triple disc coulter drill, sowing at a depth of $5 \mathrm{~cm}$ or less, was used on the three dates. In mid October, a "Hunter's Rotary Strip Seeder" drill was also used on herbicide-treated and short pastures. This drill, which cultivates a seedbed (10 cm wide) for each coulter, has enhanced seedling establishment compared with conventional drills, in the high country (de Lacy 1964, NWASCA 1985).

Cultivated ground was ploughed, fallowed, worked to a seedbed and rolled, before sowing. All herbicide-treated pasture had glyphosate $(2.2 \mathrm{~kg}$ ai/ha) applied three weeks before the September sowing. Applications were repeated one week 
before October and November sowings. A pre-emergence herbicide (simazine $1.5 \mathrm{~kg}$ ai/ha) was applied after drilling on cultivated and herbicide-treated ground. Short pasture treatments were mown to $25 \mathrm{~mm}$, to simulate close grazing, before seed was sown. Seed broadcast by hand was foot trampled onto moist soil to simulate stock treading.

Tagasaste seed from Banks Peninsula had most hard seed eliminated. This was done by rejecting the smallest and lightest seed as these fractions failed in a laboratory germination test $(85 \%$ germination over 1 month at $20 \mathrm{C})$. Seed was immersed in water at $85 \mathrm{C}$ for 1 minute, then inoculated with commercial Lotus pedunculatus rhizobia, two days before sowing.

Each site had four replicates of seven treatments in a randomised block design. Each plot was one row, $25 \mathrm{~m}$ long. Seed weight was $30 \mathrm{~g} / 1000$ seeds and $20 \mathrm{seeds} / \mathrm{m}$ were sown to ensure treatment comparisons.

Assessments. Establishment was recorded 4,8 and 12 weeks after sowing on the central $10 \mathrm{~m} /$ plot. Data were arc sin transformed before analyses but back transformed values are presented. Competition from unsown plants was noted. Rainfall, soil moisture and daily soil temperature at $10 \mathrm{~cm}$ depth were recorded on each ground preparation at each site.

\section{Management Trials}

Methods. Rooted, nodulated seedlings were planted in spring one year before defoliation treatments were imposed. Weeds were controlled with herbicides and cultivation and branching was encouraged by cutting the leading shoot from $1 \mathrm{~m}$ to $30 \mathrm{~cm}$ above ground.

Hill sites, One site was on a north slope at Diamond Harbour, Banks Peninsula, on a Takahe silt loam soil of pH 5.5. An inland site at Waikari was on an exposed nor'west slope on a Tipapa silt loam soil of $\mathrm{pH}$ 5.1. Seedlings were planted in rows 2 $\mathrm{m}$ apart, with 6 plants per row (or plot), at $50 \mathrm{~cm}$ spacing. Five replicates were planted in August 1980 and five in August 1981 within a trial comparing fodder tree species. Plants were cut to $30 \mathrm{~cm}$ above ground.

Flatland site. Two replicates of 8 tagasaste seedlings/per plot were planted in November 1982, as spaced plants with 1 plant/3 $\mathbf{m}^{2}$, on a Templeton deep silt loam soil of $\mathrm{pH} 5.7$ at Templeton Research Station. Plants were either grazed by sheep or hand cut to $50 \mathrm{~cm}$ above ground, or grazed by sheep and then trimmed $50 \mathrm{~cm}$.

Some plots were defoliated only in August or December 1983, and some in August and December 1983. All plots were either cut, or grazed and trimmed in March 1984, and subsequently all were cut in late February 1985.

Assessments. For cut treatments, forage was oven dried and weighed, and leaves and stems separated on sub samples. Indirect estimates of DM produdtion for grazed and graze/trim treatments were made by regressing the DM from cut plants on visual scores of DM from these plants, thereafter substituting the visual scores of the grazed or grazed/trim plants in the appropriate regression equation.

\section{RESULTS AND DISCUSSION}

\section{Establishment Trials}

Spring rains, were favourable (258 $\mathrm{mm}$ from September to December) Establishment was consistently better on the lighter soil site than on the deeper soil site. The latter had especially strong pasture regrowth on short pasture treatments, white clover competition on herbicide-treated pasture and wild oat competition on cultivated and herbicide-treated ground.

Seed drilled into cultivated ground gave the best establishment (Table 1). That drilled into herbicide-treated pasture also established well although germination was 
Table 1: Effect of ground preparation and sowing method' on tagasaste establishment. Mean of three sowing dates at two sites.

\begin{tabular}{llrrr}
\hline Ground Preparation & Sowing Method & \multicolumn{3}{c}{$\begin{array}{c}\text { Establishment } \\
\text { weeks after sowing }\end{array}$} \\
& & 4 & \multicolumn{1}{c}{ a } & 12 \\
\hline Cultivated ground & Duncan drill & 33.2 & 53.1 & 55.2 \\
Herbicide-treated pasture & Duncan drill & 27.4 & 44.5 & 39.7 \\
& Broadcast & 1.5 & 3.5 & 2.7 \\
Short pasture & Duncan drill & 12.3 & 16.6 & 6.7 \\
& Broadcast & 0.6 & 1.3 & 0.7 \\
I.s.d. (5\%)' & & 4.3 & 11.4 & a.7 \\
\hline
\end{tabular}

'Hunter's drill treatments omitted as they were restricted to the mid October sowing

'Based on site $\boldsymbol{X}$ treatment interaction

slower and clover competition adversely affected September and October sowings. Similar costs per plot were estimated for drilling in cultivated and herbicide-treated ground $(\$ 340 /$ ha, Contractors Federation, pers. comm. 1985). Seed drilled into short pasture gave poor establishment because of strong pasture regrowth. Many seedlings germinated but were smothered before they reached the pasture canopy. Of the few seedlings which did emerge, some later died, probably because of moisture competition from pasture.

Most broadcast seed failed to germinate probably because few seeds were effectively trodden into the soil. Seed which did penetrate the soil surface, germinated. That which remained on the surface absorbed enough moisture to start radicle growth but these did not penetrate the seed coats. Hard seed may be better overcome by scarifying seed, rather than soaking in hot water (D.J.G. Davies, pers. comm.). This used with effective stock treading might give acceptable levels of establishment in areas inaccessible to machinery.

On herbicide-treated pasture, establishment from the Duncan drill and the Hunter's drill was not statistically significant on either site (Table 2). However on short pasture, the Hunter's drill gave better establishment on the lighter soil at Burnham (Table 2). These results confirm other findings (Kaviani pers. comm) that the Hunter's drill aided seed establishment by reducing moisture competition from unsown plants.

Table 2: Effect of drilling method on tagasaste establishment, sown mid October 1965

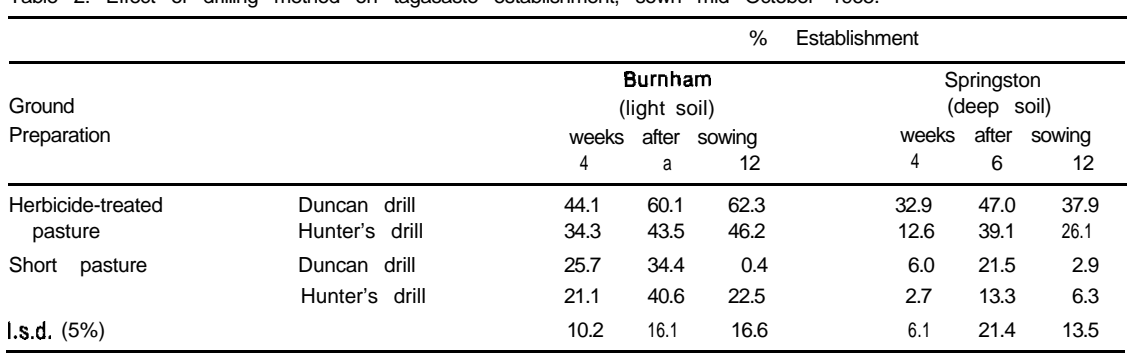

September sowings with cooler soils, were slower to germinate than later sowings (Table 3), especially on the deeper soil site. September and October sowings gave increased establishment between 4 and 8 weeks (Table 3) while November sowings were restricted by drier soils which sometimes reached wilting point. As rainfall in November and December 1985 was $70 \%$ above normal, it is likely that in most years, November sowings would fail from lack of moisture.

Management Trials

Tagasaste grew better at Diamond Harbour which received more rain and less 
Table 3: Effect of time of sowing on tagasaste establishment. Mean of Duncan drill treatments over 3 ground preparations at 2 sites.

\begin{tabular}{|c|c|c|c|c|}
\hline \multirow{3}{*}{$\begin{array}{l}\text { Time of sowing } \\
\text { (mid month) }\end{array}$} & \multicolumn{3}{|c|}{$\% \quad$ Establishment } & \multirow{3}{*}{ Temperature' } \\
\hline & & after & & \\
\hline & 4 & 8 & 12 & \\
\hline September & 12.3 & 37.3 & 33.1 & 10.9 \\
\hline October & 32.6 & 47.6 & 38.5 & 13.1 \\
\hline November & 28.1 & 29.3 & 30.1 & 16.5 \\
\hline Is.d. $(5 \%)^{2}$ & 9.6 & 14.3 & 10.3 & \\
\hline
\end{tabular}

"Mean daily $10 \mathrm{~cm}$ soil temperature, for 4 weeks after each sowing.

'Based on site $x$ treatment interactions.

wind, than Waikari. Annual production of around $1.8 \mathrm{~kg} \mathrm{DM} / \mathrm{plant}$ was sustained at Diamond Harbour once plants were well established, in this case, after one season. Annual production was lower at Waikari, about $1.3 \mathrm{~kg}$ DMlplant, and more time was needed for successful establishment (Table 4). Leaf and stem separations showed that $80 \%$ of annual yields could be eaten by sheep. With 10,000 plants/ha, yields of 13 to $18 \mathrm{t}$ DM/ha may be possible. Plant survival was excellent. Plants grew up to $2 \mathrm{~m}$ over summer, yet readily coppiced from $30 \mathrm{~cm}$ stumps. In time, a dense network of basal branches formed at stump level, occupying an area $150 \mathrm{~cm} \times 50 \mathrm{~cm}$ per plant.

Table 4: Effect of cutting on tagasaste production ( $\mathrm{kg} \mathrm{DM} / \mathrm{plant}$ ) at 2 hill sites.

\begin{tabular}{|c|c|c|c|c|c|c|c|}
\hline \multirow[t]{3}{*}{ Date } & \multirow[t]{3}{*}{ cut } & \multirow{2}{*}{\multicolumn{2}{|c|}{$\begin{array}{l}\text { Diamond Harbour } \\
\text { Plantings }\end{array}$}} & \multirow{2}{*}{\multicolumn{2}{|c|}{$\begin{array}{l}\text { Waikari } \\
\text { Plantings }\end{array}$}} & \multicolumn{2}{|c|}{ Rain (mm) } \\
\hline & & & & & & \multicolumn{2}{|c|}{ between cuts } \\
\hline & & 1980 & 1981 & 1980 & 1981 & Diamond & H. Waikari \\
\hline 1981 & May & 0.3 & & 0.1 & & & \\
\hline 1982 & Apr & 1.1 & na & 0.4 & ną & 780 & 400 \\
\hline 1983 & Feb & 1.9 & 2.9 & 0.8 & 1.1 & 600 & 260 \\
\hline & Aug & 0.2 & 0.2 & 0.2 & 0.2 & 340 & 215 \\
\hline 1984 & Feb & 1.2 & 1.4 & 1.7 & 1.2 & 520 & 366 \\
\hline & Oct & 1.0 & 0.9 & 0.7 & 0.4 & 430 & 160 \\
\hline 1985 & Feb & 1.1 & 1.3 & 1.0 & 0.8 & 210 & 70 \\
\hline & Sep & 0.5 & 0.5 & \multirow{2}{*}{\multicolumn{2}{|c|}{ Discontinued }} & 410 & \\
\hline 1986 & $\mathrm{Feb}$ & 1.7 & 1.5 & & & 308 & \\
\hline
\end{tabular}

na Not sufficient growth to cut.

On the Templeton site, plants were not defoliated (apart from leader triming) between planting in November 1982, and being experimentally defoliated in the 1983-84 season. Plots which remained untouched until defoliated in March 1984 had accumulated, on average $3.4 \mathrm{~kg}$ DMlplant. This was similar to the growth of plots cut to $50 \mathrm{~cm}$ in August 1983 and left untouched until March 1984 (3.1 kg DMlplant). However, those plots which had been grazed in August 1983, or grazed and then trimmed, grew significantly less in the 1983-84 season (1.9 kg DMlplant). Those plots which were defoliated in December 1983 (either by cutting or grazing) accumulated even less during the 1983-84 season (1.1 kg DMlplant). From March 1984 to February 1985, no plots were defoliated. But when all were cut in February 1985, those plots which had previously been grazed were still significantly less productive $(1.8 \mathrm{~kg}$ DMlplant) than plots which had been cut (3.2 kg DM/plant).

\section{CONCLUSIONS}

Tagasaste was successfully established in Canterbury by drilling seed into cultivated ground when spring soil temperatures reached about $13^{\circ} \mathrm{C}$ (at $10 \mathrm{~cm}$ ). Satisfactory seedling establishment needs pre-emergence herbicides to control weed growth for at least three months after sowing. Drilling into herbicide-treated pasture can also succeed if care is taken to eliminate problem plants such as clover 
which can compete successfully against tagasaste seedlings. Clover cannot yet be sprayed out, among young tagasaste.

Further research is needed to achieve specific plant densities with precision drilling. One plant per $\mathrm{m}^{2}$ either in a grid or with $50 \mathrm{~cm}$ between plants in staggered double row plantings, appears appropriate both for mechanical harvesting and for sheep grazing.

Broadcast seed failed in these trials. However more research is needed to enhance germination to make broadcasting more successful, especially in hill country where management trials have already demonstrated the potential of tagasaste to produce substantial quantities of leafy dry matter.

Management options for tagasaste remain open, although in the short term, more leafy material can be expected from cutting rather than grazing. Current trials will determine whether this trend is sustained after repeated defoliations.

\section{Practical guidelines}

These are offered as suggestions, pending more experience.

1. Minimise hard seed by scarifying or soaking in hot water, then inoculate with Lotus rhizobia.

2. Establish on well drained sites. Sow in spring for warmer soils and reduced frost risk and protect from rabbits and hares when young.

3. Drill into cultivated ground or herbicide-treated pasture using pre-emergence herbicides and aim for final density of not less than one plant $/ \mathrm{m}^{\prime}$.

4. Encourage low branching by cutting or grazing main shoots on young plants.

5. Periodically trim straggly branches to give better form for sheep grazing and avoid bark stripping by careful stock management.

6. Coppice to $50 \mathrm{~cm}$ for leafy regrowth.

\section{Acknowledgements}

The authors thank all co-operating farmers; R.T. Alexander for technical assistance and C.B. Dyson for statistical analyses.

\section{References}

de Lacy H. 1984. N.Z. Farmer pp 19-21.

NWASCA 1985. National Water and Soil Conservation Authority. "Streamland" 41 